\title{
Die gawe van onderskeiding as spieël vir die kerk
}

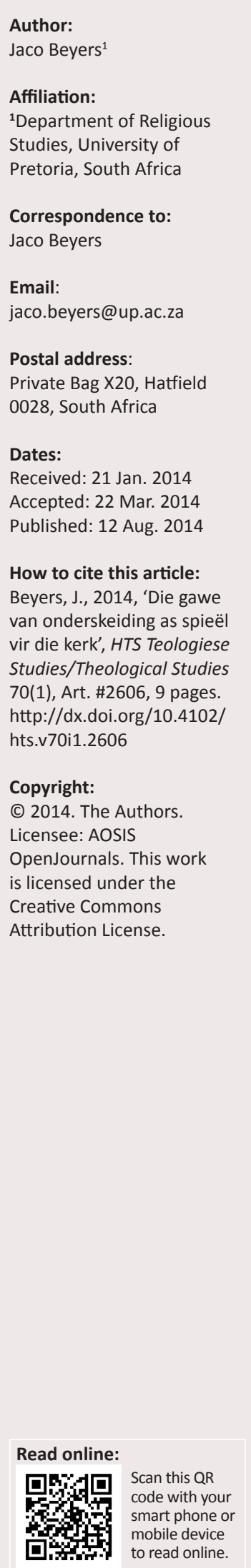

The gift of discernment as mirror for the church. In the encounter between man and the Holy, man reacts with the ambivalent emotion of fear and fascination. Man is confronted by something incomprehensible. How will man know whether this is God? Any response by man, even faith, might be a self-deception. This condition is called 'bad faith' by Sartre and Berger. In an existential struggle with the numineuse, man constantly tries to get to know God and his will. This struggle is faith. The Holy Spirit bestows the gift of faith on mankind. The pneumatic moment is when congruency is established between on the one hand the human identity arrived at in Christ and, on the other hand, the existential expression of the response to the calling by God.

\section{Inleiding}

In ontmoeting met die Heilige reageer die mens met die tegelyktydige gevoel van vrees en fassinering. Die mens word met 'n onkenbare grootheid gekonfronteer. Hoe sal ons weet of dit God is? Enige reaksie, selfs geloof, kan misleidend wees. Dit is wat Sartre en Berger bad faith noem. In 'n eksistensiële stryd met die numineuse is die mens konstant besig om te soek na God en sy wil. Die Heilige Gees gee die gawe van ware geloof. Die pneumatiese moment is wanneer kongruensie ontstaan tussen die identiteit van die mens wat verkry is in Jesus Christus en die eksistensiële uitdrukking en uitleef van hierdie identiteit as reaksie op die roepstem van God.

In die soeke na die aard van geloof, reageer die mens met vrees en fassinering in die ontmoeting met die numineuse (die Heilige). Op die aangryping deur die Heilige, reageer die mens met geloof. Hierdie geloof kan nominaal, afwesig of soekend wees. Hierdie drie moontlikhede dui op 'n inkongruensie tussen die innerlike subjektiewe ervaring van die mens en die objektiewe appél van die Heilige tot die mens. Hierdie inkongruensie staan bekend as bad faith.

Die mens word tegelykertyd met fassinering en vrees gevul in ontmoeting met die vreemde. Die gedig The Tyger van William Blake (1794) gee uitdrukking aan hierdie dubbele reaksie van die mens:

\footnotetext{
The Tyger

Tyger! Tyger! burning bright

In the forests of the night,

What immortal hand or eye

Could frame thy fearful symmetry?

In what distant deeps or skies

Burnt the fire of thine eyes?

On what wings dare he aspire?

What the hand dare sieze the fire?

And what shoulder, and what art.

Could twist the sinews of thy heart?

And when thy heart began to beat,

What dread hand? and what dread feet?

What the hammer? what the chain?

In what furnace was thy brain?

What the anvil? what dread grasp

Dare its deadly terrors clasp?

When the stars threw down their spears,

And watered heaven with their tears,

Did he smile his work to see?

Did he who made the Lamb make thee?

Tyger! Tyger! burning bright

In the forests of the night,

What immortal hand or eye

Dare frame thy fearful symmetry?
} 
In 1794 skryf die Britse digter en skilder William Blake (1757-1827) die gedig The Tyger. In sy kunswerke, sowel as in sy gedigte, verwys Blake na verskeie Bybelse temas. Alhoewel Blake alle vorme van georganiseerde godsdiens verwerp het en 'n groot kritikus van die Church of England was, bly hy 'n ortodokse leer handhaaf. Hy bevraagteken die Verligtingstendense van sy tyd maar is ook nie ten gunste van vrye, ongebonde idees nie.

In sy gedig, The Tyger, bespreek hy die emosies van vrees en verwondering as menslike reaksie op die skepping. Die Skepper het dit reggekry om diere met uiteenlopende eienskappeteskep. Dietierenlam funksioneerasopponerende simbole wat die ekstremiteite van die skeppingsmag van die Skepper verteenwoordig. Wanneer die mens met die skepping gekonfronteer word, wek dit uiteenlopende emosies by die mens; emosies van verwondering en vrees. Die tier as wrede, sterk, geheimsinnige dier laat die mens vra na hoe die Skepper van hierdie ongedierte moet wees. Net so laat die onskuld en broosheid van die lam die vraag by die mens ontstaan: As Hy in staat is om so 'n dier te skep, hoe moet die Skepper self dan wees? As die Skepper dan hierdie uiteenlopende diere wat ekstremiteite verteenwoordig, kon skep, wat sê dit oor die aard van die Skepper? As die mens reageer met vrees sowel as verwondering in konfrontasie met die skepping, wat sê dit van die emosie(s) wat 'n ontmoeting met die Skepper self by die mens sal ontlok? Rudolf Otto beskryf die mens se godsdienstige reaksie in ontmoeting met die vreemde.

\section{Rudolf Otto (1869-1937)}

Blake se gedig, The Tyger, herinner aan die menslike reaksie in ontmoeting met die transendente. Rudolf Otto beskryf die menslike reaksie op die gewaarwording van die Heilige, dit wat Otto die numineuse ([1917] 1932:5, 7) noem.

Die Heilige is 'n kategorie wat slegs binne die godsdienstige diskoers tuishoort (Otto [1917] 1932:5). Die Heilige as konsep is vir die menslike verstand (rasionaal) onbegryplik en ontoeganklik en daarom slegs gevoelsmatig kenbaar (Otto [1917] 1932:12). Die Heilige is volgens Otto ([1917] 1932:6) dit wat in alle godsdienste teenwoordig is en waarop die mens godsdienstig reageer. Otto se verstaan van godsdiens veronderstel dat die mens in relasie met 'iets' groter as die mens staan, dit wat Otto die Heilige noem, en waarsonder godsdiens nie meer godsdiens sal wees nie. Die mens reageer gevoelsmatig in reaksie op die ontmoeting met die Heilige (Otto [1917] 1932:6). Om die andersoortigheid en uniekheid van die 'iets' groter as die mens aan te dui, skep Otto die woord numineuse, afgelei van die Latyn numen. Met hierdie konsep wil Otto ([1917] 1932:7) doelbewus 'n kategorie skep wat moeilik definieerbaar is.

Otto ([1917] 1932:7) is van mening dat die mens slegs bewus gemaak kan word van die bestaan van die numineuse. Elke individu sal in reaksie op die ontmoeting met die numineuse eiesoortig reageer na 'n eie bewuswording van die numineuse. Die numineuse is slegs gevoelsmatig kenbaar.
Die ervaring en bewuswording van die numineuse kan 'n gedeelde of kollektiewe ervaring wees wat mense saambind. Hierdie bewuswording is 'n geestelike (spirituele) ervaring.

Die basiese godsdienstige gevoel by die mens word deur Schleiermacher ([1899] 1991:60, 73, 76, 85) geidentifiseer as die gevoel van afhanklikheid. Die mens in ontmoeting met die Heilige wil meer van die Heilge weet. Die mens is afhanklik van kennis oor die Heilige. Otto ([1917] 1932:12) verkies om daarna te verwys as die Kreaturgefühl, dit wil sê, die fundamentele gevoel wat alle ander godsdienstige reaksies, soos geloof, liefde en vertroue, voorafgaan. Otto beskryf die mens se tweeledige reaksie op die ontmoeting met die numineuse.

\section{Die mens reageer met vrees}

Wanneer die mens in ontmoeting met die numineuse kom, reageer die mens met vrees op die geheimenis en misterieuse waarmee die mens gekonfronteer word. Die ervaring van die numineuse word deur Otto met drie momente beskryf: die tremendum [oorweldigende], die majestas [heerlikheid], en die energie. Otto ([1917] 1932:14) verwys na die eerste van hierdie momente as die mysterium tremendum [oorweldigende misterie]. 'n Misterie, juis omdat die numineuse verborge bly, onkenbaar, onbeskryflik en buitengewoon (Otto [1917] 1932:14); 'n God wat 'absoluut onmoontlik is om te bereik' (Otto [1917] 1932:23). Vir Otto ([1917] 1932:31) bestaan die misterie eerstens daarin dat die numineuse so 'gans anders' is. Op die gewaarwording van die misterie, die numineuse, volg die gevoel van tremendum.

'n Tremendum, aangesien die mens met die natuurlike gevoel van vrees reageer op die geheimnisvolle. Hierdie vrees kan meer genuanseerd ' $n$ 'respekvolle afstand' genoem word. Dit is nie ' $n$ vrees wat weersin, paniek en ontvlugting aanhits nie, maar eerder ' $n$ vrees wat fassinering, nuuskierigheid en aangetrokkenheid wek. Schleiermacher onderskei tussen 'heilige vrees', wat ooreenstem met 'respekvolle afstand', teenoor 'natuurlike vrees' (Schleiermacher [1899] 1991:67). Die Engelse woord 'awe' omskryf die gevoel beter (Otto [1917] 1932:15). Hierdie gefassineerdheid is een van die emosies wat 'n mens ervaar wanneer die mens volgens Blake met die tier gekonfronteer word: respekvolle afstand en tog aangetrokkenheid.

In die Christelike liedereskat bestaan daar ook tekens van die emosie 'respekvolle afstand' as reaksie wanneer die mens in die teenwoordigheid van God kom. Vergelyk die woorde van Gesang 171:

Heilig, heilig, heilig is die Heer. Eng'le in die hemel buig hul voor Hom neer. Here, hoor my bede, hoor my as ek sing, en aan $\mathrm{U}$, my Vader, al my hulde bring.

Die Joodse Godsbegrip gee 'n goeie aanduiding van hierdie 'respekvolle afstand' wat daar tussen die mens en God moet wees. God is net te heilig, gevul met geregtigheid, te groot en verhewe om die mens in sy nabyheid te verduur. Die jaloerse God duld geen onheiligheid in sy teenwoordigheid 
nie. Selfs God se naam is te heilig om uitgespreek te word. Tog is dit die God wat hom oor die mens ontferm en wie in gebed aangeroep word om hulp. 'n God wat met vrees gedien word.

Otto ([1917] 1932:23) wys daarop dat die mens in die ontmoeting met die Heilige, oorweldig word. Vir hierdie ervaring gebruik Otto ([1917] 1932:23) die uitdrukking 'majestas'. In die ontmoeting met die majesteit van die Heilige, word die Heilige vir 'n wyle vir die mens kenbaar. Die mens in die moment van konfrontasie met die majestieuse, ontdek sy of haar eie onmag, eie niksheid voor die grootheid van die Heilige. Sonder om die Heilige dan volkome te ken, ontdek die mens sy of haar eie relatiwiteit voor die Heilige. Hierin lê die wortel van wat Schleiermacher die afhanklikheidsgevoel noem. Ten grondslag is die gevoel van geringheid teenoor die Heilige wat majesteus oor alles troon. Die numineuse behou die moment van vrees. Nooit word die mens die numineuse gewoond sodat die mens nie meer telkens in ontmoeting daardeur oorrompel en aangegryp word nie.

Die mate van oorweldiging deur die Heilige, laat Otto ([1917] 1932:26) die proses gelykstel aan die mistieke ervaring. Hierdie mistiek het egter niks met die 'syns-metafisika' te doen nie ([1917] Otto 1932:27).

Die derde beskrywing van die moment van ontmoeting met die numineuse beskryf Otto met die konsep 'energie' ([1917] 1932:28). Met die konsep energie wil Otto ([1917] 1932:28) wys op die vitaliteit en vibrasie van die numineuse. Die numineuse is aktief en viriel. Met hierdie beeld van 'n lewende godheid wil Otto ([1917] 1932:28) die steriele, onaktiewe beeld van die filosofiese god wat deur die rasionele en spekulatiewe geskep is, teëwerk. Die Heilige is lewend en gee lewe.

Die mens reageer dus in ontmoeting met die numineuse, met tremendum, majestas en energie. Dit is egter nie al gevoel wat by die mens gewek word nie. Die ambivalente reaksie van die mens op die numineuse word deur Otto verwoord met die uitdrukking mysterium tremendum et fascinans [misterie wat oorweldig en fassineer].

\section{Die mens reageer met verwondering (fascinans)}

In ontmoeting met die numineuse reageer die mens met 'n mysterium tremendum, soos reeds uiteengesit. Otto ([1917] 1932:43) identifiseer egter ' $n$ tweede moment wat, soos Otto dit noem, in 'n 'kontras-harmonie' met die moment van die tremendum staan. Hierdie moment noem Otto ([1917] 1932:43) die 'fascinans' [fassinering ]. Dit beskryf die gevoel dat ten spyte van vrees, die mens tog meer van die Heilige wil weet en nader aan die Heilige wil wees. Die mens verwonder hom of haar oor die numineuse en is nie net daardeur aangegryp nie. Ook hierdie moment vanfassinasie, is vir Otto ([1917] 1932:43) 'n irrasionele moment.

In ontmoeting met die numineuse is die mens nie net aangegryp nie, maar die vermoede bestaan by die mens dat die geheimnisvolle meer daaraan het as wat met die eerste ervaring waargeneem is (Otto [1917] 1932:44). Hierdie vermoede dryf die mens tot meer belangstelling en ondersoek. Die numineuse dryf die mens tot aksie. Hierdie reaksie van die mens in ontmoeting met die numineuse gaan oor in wat Otto ([1917] 1932:45) omskryf as 'sakrale handelinge' wat bestaan uit rites en kommunikasie. Op soeke na die nabyheid van die numineuse kom die mens naby aan 'n mistieke belewenis wat vir Otto ([1917] 1932:45) bestaan uit, aan die een kant, magies-kultiese aksies en, aan die ander kant, die shamanistiese ervaring van besitneming en inwoning deur die numineuse. Die ontmoeting met die numineuse gaan deur die fassinering oor in 'n subjektiewe uitreiking na die numineuse en 'n obkjektiewe beslaglegging deur die numineuse. Hierdie proses noem Otto die 'vita religiosa' [lewe van geloof] - die godsdienstige bestaan ([1917] 1932:46). Eers in hierdie proses word sekondêre belewenisse deel van die menslike reaksie op die numineuse. Nou eers is daar plek vir vertroue, geloof en liefde (Otto [1917] 1932:47).

As dit is hoe die mens die numinuese ontmoet en in reaksie daarop reageer, hoe bepaal die mens die egtheid van hierdie belewenis? Hoe weet ' $n$ mens dit is God met wie jy te doen het? Hoe sal die mens God erken in die ervaringe wat aan ekstase en fassinering grens? Hoe kan die mens onderskei tussen dit wat die ware gewaarwording en belewing van die goddelike is en dit wat 'n subjektiewe illusie of hallusinasie is? Hoe weet ' $n$ mens dit is God wat vra om in geglo te word? Hoe sal die mens kan onderskei? In hierdie verband sal dit nodig wees dat die mens onderskei tussen ware en valse geloof - faith and bad faith. Aandag word eersvolgens aan die saak van bad faith gegee.

\section{Bad faith}

Die konsep bad faith ontstaan vanuit die filosofie van die eksistensialiste, met spesifieke verwysing na die denke van die Franse filosoof Jean-Paul Sartre. Die eksistensiële filosoof leer iets oor die eerlikheid van menslike bestaan; eerlik teenoor jouself, en eerlik teenoor ander oor jou eie bestaan en ervaringe.

\section{Jean-Paul Sartre}

Die doel van die filosofiese benadering bekend as eksistensialisme is om die ware menslike wese te beskryf. Kaufmann (1956:11) beskou eksistensialisme as 'n betoog teen die tradisionele filosofie. Filosowe wat as eksistensialiste beskou word, het volgens Kaufmann (1956:12) twee kenmerke in gemeen: individualisme en ' $n$ afkeer van tradisionele filosofie. Met die klem op individualisme, wil filosowe te kenne gee dat hulle met geen skool van denke of sisteme geassosieer wil wees nie. Eksistensialiste se ongemak met tradisionele filosofie is juis dat dit te akademies en verwyderd van die werklike lewe geraak het. Die mens in sy of haar leefwêreld is die belang van die eksistensialiste.

In sy boek getiteld Being and nothingness (1956) probeer die Franse filosoof Jean-Paul Sartre juis die vraag beantwoord wat is die wese van die mens? Hy beskryf die mens se wese as: 
My consciousnesss is not restricted to envisioning a négatité. It constitutes itself in its own flesh as the nihilation of a possibility which another human reality projects as its possibility. (bl. 47)

Die mens se bewussyn is die ontkenning dat my bewussyn dieselfde is as die mens naas my se bewussyn. Ek is wie ek is omdat ek nie jy is nie. Wanneer hierdie negatiewe gesindheid van die mens wat na buite gerig is, skielik omgedraai word en na binne gerig word, noem Sartre dit bad faith (Sartre 1956:48). In Afrikaans sal die naaste vertaling daaraan kan wees om te praat van 'nie-goeder trou' of 'kwade trou'. Sartre (1956:58) meld dat die teendeel van bad faith is sincerity - opregtheid of egtheid. Daar bestaan dus 'n inkongruensie tussen die wese van die mens en die uitdrukking van hierdie wese. Of om Lefevbre ([1974] 1991:33) se terminologie in te span: die conceived identiteit is nie kongruent, of dieselfde as die lived identiteit, nie. Wie die mens is, stem nie ooreen met hoe die mens hierdie identiteit uitleef nie. Die mens is nie eerlik met hom- of haarself nie. Ek is nie wat ek is nie (vgl. Sartre 1956:58).

Meestal sal 'n persoon wat bad faith vertoon, beskuldig word dat hulle vals is, of vir hulleself lieg. Hierdie leuen vir jouself is anders as die leuen in die algemeen (Sartre 1956:48). Die aard van ' $n$ leuen impliseer dat ' $n$ mens die volle waarheid ken, maar dit verborge hou. Bad faith as leuen vir 'n mens self impliseer dat ' $n$ mens onbewus is van iets of van verkeerde inligting oortuig is. Sartre (1956:49) dui aan dat iemand wat bad faith beoefen, verberg 'n onaangename waarheid of bied as die waarheid aan iets wat 'n aangename onwaarheid is. Bad faith beteken dus dat ek van myself die waarheid weerhou. Dit is wat Sartre, volgens Kaufmann (1956:241), self-deception noem. Met bad faith is daar slegs een bewussyn ter sprake. Ek weerhou iets van myself. Bad faith kan nie van buite die mens op die mens af forseer word nie. Dit is iets wat die bewussyn aan homself doen. Die een wat die leuen vertel en die leuen aanhoor is een en dieselfde persoon. Die mens behoort in goeder trou bewus te wees van die bad faith wat my bewussyn affekteer.

Om die konsep van bad faith te verduidelik, skryf Sartre (1965) 'n dramastuk getiteld The flies. In The flies leef die inwoners van die antieke stad Argos onder die indruk dat hulle 'n swaar las van skuld aan hulle koning se moord dra. In werklikheid is hulle onbewus van die geheim dat hulle eintlik vry van enige skuld is (Sartre 1965:72). Die oorbodige skuldgevoel bepaal hulle hele bestaan. Die inwoners het hulleself dus van die waarheid van 'n onwaarheid oortuig. Hierdie oortuiging het hulle identiteit geword en nou leef hulle ooreenkomstig hierdie (valse) identiteit. Hulle hele bestaan is 'n bestaan van konstante berou (Sartre 1965:15) en soeke na vergifnis. Vrees en skuldgevoel by mense is 'n plesier vir die gode (Sartre 1965:17).

Jaarliks herdenk die inwoners van Argos die dood van hulle koning deur die poorte van die dood oop te maak sodat die siele van die dooies die stad kan teister as herinnering aan en straf op hulle aandeel aan die moord op die koning. Die stad word voortdurend aan hulle oortreding herinner deur die teenwoordigheid van swerms vlieë wat konstant om die inwoners saamkoek. Die vlieë funksioneer as simbool van hulle ongegronde skuldgevoel (Sartre 1965:13). Prinses Electra leef as slavin in die paleis van die nuwe koning. Sy is die dogter van die gestorwe koning en tog leef sy skynbaar vrywillig soos 'n slavin as selfopgelegde straf vir haar aandeel aan haar vader se dood. Sy leef nie kongruent met haar ware identiteit nie. Sy leef in selfbedrog net soos die inwoners van die stad. Selfbedrog ontken menslike vryheid.

Die prins, Orestes, verskyn op die toneel en beplan om die moordenaar van sy vader, die koning, om die lewe te bring. Vreesloos vir skuldgevoel beplan hy om die moordenaars van sy vader dood te maak. Die gevolg is dat hy vry voel. Die vryheid behels dat hy 'one with myself' voel, '[b]eyond anguish, beyond remorse. Free' (Sartre 1965:87). Vryheid is om een te wees met jouself. Tot hierdie vryheid spoor Orestes sy suster Electra aan: kom ons gaan 'towards ourselves', moedig hy haar aan (Sartre 1965:99). Electra kan nie hierdie stap neem nie en verbeur daarmee haar vryheid.

Orestes neem die besluit om sy vader se dood te wreek. Met die moord op sy stiefpa en moeder word die dood van sy vader finaal gewreek. Voor die god Zeus het Orestes geen vrees of berou oor sy optrede nie (Sartre 1965:75, 78). Sy bose daad is die regte daad. Hy, as vry mens (Sartre 1965:72, 74, $87,95)$, besef dat met vryheid kom verantwoordelikheid. Orestes neem verantwoordelikheid vir sy optrede en dra die gevolge van sy daad, al sou dit die straf van Zeus beteken (Sartre 1965:93, 94). Die held Orestes sterf as vry mens wat bereid is om verantwoordelikheid vir sy optrede te neem (Sartre 1965:103).

Mensike vryheid is belangrik. Soms gebruik mense die vryheid om te ontken dat vryheid bestaan. Dit noem Sartre bad faith. Bad faith is die selfbedrog wanneer menslike vryheid ontken word. Die mens is vry en moet vryheid gebruik om verantwoordelikheid te neem vir sy optrede. Die mens wat bang is vir die gevolge van enige keuse in vryheid gemaak, besit bad faith.

Om nie 'n reaksie van geloof in die numineuse na 'n ervaring van die mysterium tremendum et fascinans nie te kies nie, is bad faith. Om aangegryp te wees deur en gefassineer wees met die numineuse vra van die mens 'n reaksie. Deur nie in vryheid te kies nie, skep die mens inkongruensie tussen die innerlike gevoel en gewaarwording van die numineuse en uiterlike uitdrukking van geloof in die numineuse. Die mens lieg dus vir hom- of haarself oor die ervaring met die numineuse. In ontmoeting met die ware lewende God, kan die mens nie anders as om in geloof te reageer nie. Hierdie keuse tot geloof vereis ' $n$ uiterlike lewe in kongruensie met die innerlike oortuiging.

Oor die aard van godsdiens binne die konteks van bad faith, skryf die sosioloog Peter Berger soos volg. 


\section{Peter Berger}

Berger se teorie van die skeppingsaktiwiteit van die samelewing behels dat die mens deur die kollektiewe prosesse van eksternalisering, objektivering en internalisering die menslike wêreld skep as objektiewe realiteit (Berger 1967:81). Die samelewing is dus die produk van kollektiewe menslike aktiwiteit. Die mens word dus gekonfronteer deur die eksterne realiteit as DIE realiteit.

Godsdiens is deel van die wêreld wat die mens skep. Godsdiens is volgens Berger (1967:89) die wêreld wat deur die mens geprojekteer word, dus 'n wêreld wat nie regtig bestaan nie maar waarvan die mens hom- of haarself oortuig dat dit bestaan. Godsdiens is die vermoë van die mens om te vervreem par excellance, volgens Berger (1967:81). Met godsdiens skep die mens 'n wêreld wat uit die 'gans andere' bestaan (Berger 1967:87). Waar Otto die objektiewe bestaan van die gans andere (numineuse) veronderstel, verklaar Berger dat die mens subjektief bygedra het tot die bestaan van die gans andere.

Volgens Berger lieg ons vir onsself. Ons is skuldig aan selfbedrog. Jy oortuig jouself van een ding en dan tree jy op volgens ander reëls. Veral in 'n sosiale opset is die mens skuldig aan selfmisleiding. Ons neem waar wat om ons gebeur en ons heg betekenis daaraan. Die betekenis is egter subjektief en bly my eie weergawe van dit wat ek in die samelewing waarneem (Berger 1967:159). 'n Samelewing kan gebou wees op valse idees en gebruike. Sosiale boosheid is gebou op sosiale gekonstrueerde rolle (Berger 1967:160).

Objektivering impliseer die produksie van 'n egte sosiale wêreld, buite die mens. Internalisering behels dat die sosiale wêreld sal bekend staan as die realiteit in die bewussyn van die indiwidue in die samelewing. Internalisering behels die skep van 'n dubbele bewussyn, naamlik die gesosialiseerde en niegesosialiseerde elemente (Berger 1967:83). Hierdie dubbele bewussyn kan tot gevolg hê dat die een bewussyn vervreem kan raak van die ander. Die een bewussyn word lynreg opgestel teenoor die ander. Of anders gestel, die duplisering van bewussyn het tot gevolg dat ' $n$ innerlike konfrontasie tussen die gesosialiseerde en nie-gesosialiseerde elemente binne die self plaasvind (Berger 1967:84). Hierdie duplisering lei tot ' $n$ innerlike gesprek wat reflekteer word in 'n uiterlike gesprek tussen die indiwidu en samelewing. Berger (1967:85) verwoord die aktiwiteit soos volg: die mens produseer 'andersheid' binne en buite homself as gevolg van sy lewe in die samelewing. Die mens word dus vreemd vir homself op grond van identiteit (wat innerlik verwek word) en sosiale self (wat ekstern uitdrukking vind) (Berger 1967:85). Die gevolg is vervreemding. Berger (1967:85) beskryf die vervreemding as die dialektiese verhouding tussen die indiwidu en die wêreld waarbinne die indiwidu leef en dan verlore gaan in die bewussyn. Vervreemde bewussyn is ondialektiese bewussyn (Berger 1967:85).

Hierdie vervreemding noem Berger die gevolg van 'vals bewussyn' (Berger 1967:86). Dit is vals want, al neem die mens deel aan die produksie van hierdie wêreld, woon die mens steeds binne hierdie vervreemde wêreld. Die mens skep 'n wêreld wat vreemd aan die mens is (Berger 1967:86). Die mens kan nie 'n objek word nie, maar slegs homself beleef as 'n objek deur sy eie ervaringe te vervals.

Berger identifiseer godsdiens as die kragtigste agent wat vervreemding bewerk (Berger 1967:87). Godsdiens is ' $n$ vorm van vals bewussyn, nie in die sin dat godsdiensoortuigings vals is nie, maar dat die godsdienstige voorstelling van die kosmos die mens se sosio-kulturele wêreld wat deur die mens se bewussyn geskep is, vervals (Berger 1967:90). Hierdie vervalsing noem Berger (1967:90) mistifisering. Die mens skep 'n sosio-kulturele wêreld. Godsdiens het tot die gevolg dat die sosio-kulturele wêreld bedek word met misteries wat hulle oorsprong in niemenslike oorsprong het. Hierdie mistifisering van die sosio-kulturele wêreld maak dat die mens nie meer die mensgemaakte sosio-kulturele wêreld kan begryp nie (Berger 1967:90). Op so 'n manier dra godsdiens by tot die vervreemding van die mens van sy wêreld.

Die ervaring van die 'Heilige' is voorwaar ' $n$ ervaring van die 'gans andere' (Berger 1967:87). Hierdie andersheid is die aanbidding van dit wat alle menslike bestaan transendeer, die absolute verwondering oor die numineuse. Die mens is gevul met verwondering en vrees in ontmoeting met die 'Heilige'. Vergelyk in hierdie verband Rudolf Otto se verklaring van die mens se reaksie van vrees en verwondering in ontmoeting met die numineuse (Otto 1932).

Hierdie wêreld van die 'Heilige' is niks anders as menslike projeksies nie (Berger 1967:89), dit wil sê, mensgeskonstrueerde wêrelde. Die objektiwiteit van godsdienstige konstruksies van betekenis is geproduseerde objektiwiteit (Berger 1967:89). Die gevolg is dat die godsdienstige konstruksies van betekenis, volgens Berger (1967:89), niks anders as 'vervreemding projeksies' is nie. Godsdiens veronderstel en poneer die bestaan van wesens en magte binne die realiteit van die mens, wat egter vreemd aan die wêreld van die mens is (Berger 1967:89). Die gevolg is dat godsdiens die mens vervreem van die realiteit en in der waarheid die mens vervreem van homself (Berger 1967:90).

Godsdiens mistifiseer sosiale instellings tot op 'n vlak waar die instellings nie meer die produk van menslike aktiwiteit is nie, maar gesanksioneer is as wetlike goddelike instellings (Berger 1967:90). Berger gebruik die voorbeeld van die huwelik as sosiale instelling wat so met misterie belaai word dat dit goddelik voorskriftelik word en uiteindelik funksioneer as 'n menslike nabootsing van die aksies van die gode, in hierdie geval die nabootsing van die hieros gamos van die gode (Berger 1967:91). Sosiale instellings word dan begrond as goddelike opdragte en nie meer as menslik wêreldskeppende aktiwiteite nie. Dit lei tot 'n verdere vervreemding van die mens van hom- of haarself.

Die rolle wat die mens in die samelewing aanneem word goddelik gesanksioneer. Geinternaliseerde rolle word 
deel van die mens se identiteit en deel van die mens se bewussyn (Berger 1967:92). Wanneer godsdiens hierdie geinternaliseerde rolle met misterie bedek, vind verdere vervreemding plaas deur die skep van 'n dubbele bewussyn. Berger dui aan dat hierdie proses egter ook lei tot 'n verdere proses van falsifikasie wat hy bad faith noem (Berger 1967:93).

Berger (1967:93) definieer bad faith as die proses waardeur die mens gedwonge voel om 'n bepaalde keuse te maak omdat dit die noodsaaklike keuse skyn te wees. So kan die mens byvoorbeeld ' $n$ bepaalde aksie kies omdat die mens met 'n bepaalde rol geïdentifiseer het wat die bepaalde aksie toelaat (Berger 1967:93). Berger (1967:93) gebruik die voorbeeld van die huwelik. 'n Eggenoot kies om sy seksuele begeertes op sy eie eggenote te rig, aangesien hy geen ander keuse het op grond van die wyse waarop sy rol binne die huwelik sy seksuele aktiwiteite geprogrammeer het nie. Die eggenoot voel gedwonge om 'n keuse te maak omdat hy sy rol in die huwelik as die programmering van sy aksies verstaan.

Alternatiewelik beskryf Berger (1967:93) bad faith as 'n vorm van vals bewussyn waar die dialek tussen die gesosialiseerde self en die self verlore gaan in bewussyn. Vervreemding en vals bewussyn behels 'n skeiding in die bewussyn tussen die mens en die produkte van sy skepping (Berger 1967:93). Die mens identifiseer so met die interne rol en die sosiale identiteit wat aan die rol toegeken is, dat die mens geen ander opsie oorweeg as wat binne hierdie beperkinge voorgeskryf word nie. Sosiale tipe en subjektiewe identiteit vloei ineen in die mens se bewussyn en skep daardeur 'n vervreemde identiteit (Berger 1967:94). Die mens wat vanuit hierdie identiteit leef, tree op vanuit bad faith (Berger 1967:94).

Bad faith het tot gevolg dat die mens se keuses vooraf bepaal is. Daar is geen onsekerhede of oorwegings van moontlike alternatiewe nie. Bad faith skep 'n gerealiseerde identiteit waar daar geen onsekerheid bestaan oor 'wie ek eintlik is' nie (Berger 1967:94).

Bad faith word volgens Berger (1967:95) nie net deur godsdiens teweeg gebring nie, maar kan sonder die inwerking van godsdiens plaasvind. Die mistifiseringsproses van godsdiens hou die illusie van 'n outnome wêreld in stand en bevestig die verinnerliking van hierdie wêreld in die bewussyn van die indiwidu (Berger 1967:95). Innerlike rolle ontvang misterieuse mag op grond van die legitimering deur godsdiens. Die indiwidu verstaan dan sosiale identiteit as iets heiligs omdat die gode dit so gewil het (Berger 1967:95). Op so 'n wyse word sosiale identiteit nie meer beskou as menslike skepping nie, maar as gegewe feit. Die mens se sosiale rol word nou beskou as goddelik gewil en goddelik bepaal. Die mens, in die uitleef van die sosiale rol gee uitdrukking aan die uitleef van die goddelike wil. Die sosiale identiteit kan die lokalisering van die heilige word (Berger 1967:95).

Die gevolg is dat die mens binne 'n wêreld bestaan wat deur homself geskep is. Hierdie skeppingsproses is deur die gode gewil. Die gode bestaan onafhanklik van die wêreld wat deur die mens geskep is (Berger 1967:95). Godsdiens dra dus by tot hierdie vervreemding tussen die mens en die wêreld. Die geprojekteerde sfeer van betekenis hang dus as 'n misterieuse ander wêreld, as 'n vreemde realiteit bo oor die wêreld van die mens (Berger 1967:96). Die mens word dus totaal en al vervreem van die mensgemaakte wêreld deur die heilige as 'gans andere' te tipeer. Die verhouding met die heilige word dan nou 'n verhouding van absolute afhanklikheid. (Vergelyk in hierdie verband Schleiermacher se stelling dat die gevoel van afhanklikheid die basiese gevoel grondliggend aan alle godsdiens is.)

Die mens skep die gode en tegelykertyd voel die mens volledig afhanklik van die gode. Die wêreld van die gode funksioneer outonoom en kan die wêreld van die mens beinvloed en selfs verander. Die mens en die mensgemaakte wêreld staan in ' $n$ dialektiese verhouding tot mekaar. Die vraag of hierdie projeksies meer kan wees as bloot dit, is nie ' $n$ vraag wat sosiologie kan beantwoord nie. Die feit dat die mens godsdiens as so ' $n$ belangrike element beskou, is aanduiding van die mens se intense soeke na betekenis (Berger 1967:100). Die mens probeer realiteit menslik betekenisvol te maak (Berger 1967:100). Die prys vir hierdie soeke na betekenis ten alle koste, is godsdienstige vervreemding (Berger 1967:101).

Volgens hierdie verstaan van bad faith, soos uiteengesit word deur Sartre en Berger, ontstaan daar vele vrae. Hoe onderskei die Christen in ontmoeting met die numineuse dat dit werklik God is? Hoe kies die mens om te glo? Hoe leef die mens 'n nuwe identiteit in Christus uit, sonder om in bad faith (self-misleiding) te verval?

\section{Identiteit en kongruensie}

In ontmoeting met die Heilige gebeur iets met die mens. Die mens reageer met vrees en fassinering (vgl. Otto [1917]1932). Die resultaat is dat die mens aangegryp en aangespreek voel deur die ervaring met die numineuse.

Die aangryping deur die numineuse kan lei tot die keuse van geloof by die mens. Die appél van die God wat openbaar en tog versluierd bly (Otto [1917] 1932:129), maak dat die mens as skepsel hierdie genadige God beter wil leer ken. Die mens se aangetrokkenheid tot God is nie net kognitief nie, maar ook gevoelsmatig (Otto [1917] 1932:128). Met die konsep van gevoelsmatigheid dui Otto ([1917] 1932:131) op die irrasionaliteit van geloof. Otto ([1917] 1932:128, 132) is van mening dat dit ook die wyse is waarop Luther die ontmoeting tussen God en mens verstaan het. Die gevoelsmatige reaksie van die mens op die ontmoeting met die numineuse, bring Otto ([1917] 1932:131) in verband met die werking van die Gees.

Vir Luther is hierdie 'kontras-harmonie' (Otto [1917] 1932:132) die kernmoment van geloof: 'n onkenbare God wat Homself kenbaar maak, 'n ontoeganklike God wat toeganklik word. God is verhewe en verborge vir die menslike verstand (Otto [1917] 1932:133). Die onbegryplikheid en onverklaarbaarheid 
van God maak dat die mens buig voor hierdie God gevul met majesteit. Voor hierdie God, kan die mens egter ook met vreugde dans en jubel oor die genade wat God bekendmaak (Otto [1917] 1932:137).

Volgens Otto ([1917] 1932:138) is daar twee eienskappe van geloof by Luther te bespeur: geloof as erkenning van God en liefde vir God. Volgens Otto ([1917] 1932:138) meen Luther dat geloof die siel se geheimsinnige metode is om eenheid met God te bewerk. Vir Luther is geloof die 'pneumatiese krag van erkenning' (Otto [1917] 1932:138). Hierdie element speel later 'n belangrike rol in die kongruente geloofskeuse en -lewe. Geloof is die mistiese voorwaarde in die gees van die mens om die onbegryplike waarheid op te neem en te erken (Otto [1917] 1932:138). Geloof is die 'aktiewe, magtige, bedrywige iets' in ons wat die affektiewe in ons dryf (Otto [1917] 1932:138). Otto ([1917] 1932:138) dui daarop dat volgens Luther is geloof meer as sieletroos, gewetensvrede of 'n gevoel van geborgenheid. Geloof is 'n kindskapgevoel (Otto [1917] 1932:138). Luther was daarop bedag om geloof nie te reduseer tot ' $n$ rasionele keuse nie. Hierdie verstaan van geloof by Luther, het daartoe gelei dat sommiges Luther verkeerdelik beskuldig het van 'n mistieke interpretasie van geloof (Otto [1917] 1932:139).

Geloof het 'n effek op die mens. Deur geloof kom daar 'n verandering in die identiteit van die mens. Luther verduidelik hoe God die eens goddelose mens se wese deur Jesus Christus verander. God bedoel dat die nuwe mens nou sy liefde in die wêreld moet reflekteer. Die vraag word dan nou: Hoe reflekteer Christene se eksistensie God se intensie? Dit vra 'n daaglikse keuse om te bestaan soos wat God vereis. Vergelyk in hierdie verband Otto ([1917] 1932:46) se konsep van 'n vitareligiosa [vertaling] wat 'n voortdurende lewe van geloofskeuses veronderstel. Onderskeiding is nodig om te bepaal hoe die identiteit uitdrukking vind in die roeping.

Die mens kan egter kies om nie met geloof te reageer op die aangryping deur die numineuse nie. Dan ontstaan 'n inkongruensie tussen die subjektiewe fassinering van die mens en die objektiewe appél van die numineuse op die mens. Vergelyk Berger se beskrywing van die dubbele bewussyn. Die mens word vreemd vir hom- of haarself op grond van identiteit (wat innerlik verwek word) en sosiale self (wat ekstern uitdrukking vind) (Berger 1967:85).

Geloof as keuse en reaksie op die ontmoeting met die numineuse kan 'n keuse in bad faith wees (vgl. Berger 1967:93). As die mens gedwonge voel om so 'n keuse tot geloof te maak, is dit 'n keuse wat nie op grond van innerlike oorwegings gemaak word nie, maar op grond van eksterne en sosiale dwang. Geloof kan 'n keuse wees op grond van sosiale en kulturele reëls. Mense maak geloofskeuses omdat hulle voel dat hulle keuses so geprogrammeer is deur sosiale instellings. Voorbeelde hiervan sou stellings soos die volgende insluit:

- 'Hier by ons lê almal belydenis van geloof op 17 jarige ouderdom af.'
- 'Dominees moet ' $n$ voorbeeld en verdediger van die ware leer wees.'

- 'Eens gelowige, altyd gelowige; sonder enige sweem van twyfel.'

Die gevolg is dat geloofskeuses uitgeoefen word sonder 'n kongruensie met die innerlike oortuiging. Die mens mag dalk selfs hom- of haarself oortuig dat 'n keuse vir geloof reeds gemaak is. Hierdie skynbare geloof is gewoon nominaliteit (Otto [1917] 1932:128) en skep inkongruensie. Hierdie inkongruensie is bad faith, 'n self-misleiding, 'n leuen vir die self.

\section{Pneumatiese moment}

Wat is die aard van geloof? As die mens in reaksie in ontmoeting met die numineuse reageer met vrees en fassinering, en geloof ' $n$ moontlike reaksie is, wat is geloof dan? Die eintlike vraag is dalk eerder hoe sal die mens weet om in onderskeiding in geloof te reageer op die numineuse. Wat sal maak dat die reaksie van die mens nie ' $n$ onegte reaksie op die numineuse is nie en maak dat die mens sodoende in bad faith reageer nie?

Volgens Deist (1984) reageer mense verskillend in geloof. Deist (1984:9) onderskei tussen dag- en nagdissipels, dié wat maklik glo en dié wat moeilik glo. Mense glo, maar die besluit tot geloof kom moeiliker by party mense. As voorbeeld van 'n nagdissipel noem Deist (1984:11) Nikodemus, wat letterlik in die nag na Jesus toe gekom het met vrae oor wat sy verhouding met God moet behels. Vir Otto ([1917] 1932:132) sowel as Deist (1984:10) is Job 'n verdere voorbeeld van 'n nagdissipel, een wat verstom staan voor die grootsheid van God, so oorweldig dat hy nouliks 'n keuse tot geloof kan maak. Die nagdissipels is mense wat glo, maar nog deur onsekerheid beetgepak word en daarom nog vele vrae oor geloof het. Dit maak nie dat die geloof van dag- en nagdissipels kwalitatief verskil nie (Deist 1984:12). Albei glo. Nagdissipels is die tipe mens wat so oorweldig deur die mysterium tremendum word dat die gevoelsvolle reaksie nie genoegsame reaksie vir hulle is nie. Hulle verstaan (kognitief) nie die numineuse waarmee hulle gekonfronteer word nie. Die fascinans is egter steeds by die nagdissipels teenwoordig sodat hulle aandag gefokus bly op die numineuse. Hulle wil dit wat hulle (nog) nie verstaan nie, beter leer ken. Geloof is nie 'n eenvoudige saak nie (Otto [1917] 1932:131).

Otto ([1917] 1932:138) het reeds daarop gewys dat Luther geidentifiseer het watter rol die Gees in geloof speel. Die Gees help die mens onderskei. Dit wat by Luther bekendstaan as die 'pneumatiese erkenningskrag' wil ek hier die pneumatiese moment in geloof noem. Die Heilige Gees dra by tot die moment van onderskeiding tussen die ambivalente gevoel van vrees en fassinering en maak dat die mens desondanks 'n keuse vir geloof kan maak.

Niemandt (2013:186) identifiseer die rol wat die Heilige Gees speel in die eksistensiële uitdrukking van die kollektiewe identiteit van gelowiges in kerk-wees. Die Heilige Gees gee 
die krag om te onderskei wat die ware identiteit van die kerk moet wees en die krag om kongruent met hierdie identiteit te leef. Die Heilige Gees bring kongruensie tussen identiteit en roeping.

Niemandt (2013) werk hier met die aanname dat God is geinteresseerd in die alledaagse bestaan van mense. Verder neem hy aan dat gelowiges (kollektief as die kerk) kan en moet deelhê aan God se besig wees in die wêreld.

Die kuns wat die kerk moet aanleer is om te onderskei hoe en waar die kerk kan deelneem aan God se besig wees in die wêreld. Hiervoor benodig die kerk die gawe van onderskeiding. Deel van die proses van onderskeiding lê vir Niemandt (2013:72) by die kerk se gewilligheid om te luister. Hiermee bedoel Niemandt dat die kerk hermeneuties (2013:80-82) met die teks sowel as die konteks moet omgaan; as't ware eksegese van die tyd moet doen om te onderskei hoe en waar God besig is. As verdere deel van die proses van onderskeiding, dui Niemandt (2013:118) die belang van gebed aan. Deur gebed is die gelowige soekend na God se plan.

Aansluitend by Niemandt se argument is die Wêreldraad van Kerke (kyk Word Council of Churches) se dokument (Together towards life 2012) wat rigtinggewend is vir die verstaan van evangelisasie en sending. Hierdie dokument dui op die plek van die Heilige Gees om die kerk te help om te bepaal waar God reeds in die wêreld besig is. Die Gees lei die kerk om in te val by God se werk wat reeds aan die gebeur is. Op so 'n manier lei die Gees die kerk om te onderskei hoe die kerk behoort kerk te wees. Die Gees skep op so 'n wyse kongruensie tussen die identiteit van die kerk en die roeping van die kerk:

One of the gifts of the Spirit is discernment of spirits (1 Corinthians 12:10). We discern the Spirit of God wherever life in this fullness is affirmed and in all its dimensions, including liberation of the oppressed, healing and reconciliation of broken communities and the restoration of the creation. (World Council of Churches 2012:4, par. 24)

Die uiteinde van geloof is dat 'n spiritualiteit van soeke nodig is. Onderskeiding benodig 'n soekende gees by die mens. Dit behels 'n bereidheid om nie staties in die wêreld te verkeer nie, maar voortdurend aktief te luister en te soek na waar God doenig is en om daar in te val. Saligheid is nie ' $n$ salige toestand vir die gelowige nie. Verlossing is ' $n$ wekroep tot aksie. Hierdie aksie begin deur soekend besig te wees na waar is God, is dit God en wat wil God van my? Net soos wat Deist met die soeke van die nagdissipel sinspeel op die voortdurende vrae na antwoorde, is dit die taak van gelowiges om voortdurend, soekend deur die wêreld te gaan. Nie soekend soos mense wat nie weet waarna hulle soek nie, maar soos mense wat worstel met die tyd waarin ons leef om te bepaal hoe die stem van God hoorbaar is en hoorbaar gemaak kan word in sulke omstandighede.

\section{Samevatting}

Wat is die aard van geloof? Die mens reageer met vrees en fassinering in die ontmoeting met die numineuse (die Heilige). Op die aangegryp wees deur die Heilige, reageer die mens met geloof. Hierdie geloof kan nominaal, afwesig of soekend wees. Hierdie drie moontlikhede dui op 'n inkongruensie wat daar tussen die innerlike subjektiewe ervaring van die mens en die objektiewe appél vandie Heilige tot die mens kom, bestaan. Hierdie inkongruensie is bad faith - 'n vervreemding vir die mens.

Geloof ontstaan as gevolg van die pneumatiese moment. Hierdiegeloof kan niein strata, vlakkevan kwaliteit, onderskei word nie, alhoewel sommige nog twyfel en soekend bly midde in geloof. Dit is wat Deist (1984:9) nagdissipels noem. Die Heilige Gees help die mens onderskei om waarlik ten spyte van vrae en twyfel gefassineer deur God se grootheid in geloof geanker te bly. Die Heilige Gees lei die gelowige om kollektief te ontdek waar God bedoel kerk, kerk moet wees. Op die manier gee die kerk eksistensieël uitdrukking aan God se intensie met die kerk. Die identiteit van die kerk (ekklesiologie) is kongruent met die roeping (eksistensie) van die kerk. Bad faith het oorgegaan in 'n vrye uitdrukking (vgl. Sartre 1965:103) van dit wat die kerk waarlik is - 'n ontdekking van ware indentiteit: 'n beweeg na onsself toe (vgl. Sartre 1965:99) om ons eie identiteit te ontdek en dan te leef soos wat ons identiteit in Christus bepaal.

In ontmoeting met die Heilige word 'n mens gekonfronteer met vrees en fassinering. Die mens moet onderskei of dit God is waarmee ek te doen het. Berger (1967:93) meen dit is 'n mensgekonstrueerde wêreld waarin ons leef, 'n projeksie wat 'n dubbele bewussyn skep. 'n Mens moet onderskei. Daarop moet die mens onderskei hoe reageer ek op die ontmoeting met die Heilige. Sartre (1956:58) meen dat 'n mens kan voorgee om te glo, en so 'n inkongruente bestaan voer deur nie te wees wat jy is nie. Die onderskeiding kom deur die Heilige Gees. Onderskeiding is ' $n$ gawe van die Gees (1 Kor $12: 10$ ). Net so is geloof 'n gawe van die Gees (Ef 2:8). Deist (1984:10) wys op die tydsame aard van die proses van geloof. Nag- en dagdissipels verskil in hulle reaksie in geloof. Die Heilige Gees help onderskei of dit God is met wie ek te doen het en hoe ek moet reageer. Niemandt (2013:186) dui aan dat die Gees help om te onderskei waar in die wêreld is God werksaam, en wil God dat gelowiges inval by sy werk.

\section{Erkenning Mededingende belange}

Die outeur verklaar dat hy geen finansiële of persoonlike verbintenis het met enige party wat hom nadelig kon beïnvloed in die skryf van hierdie artikel nie.

\section{Literatuurverwysings}

Berger, P., 1967, The Sacred Canopy: Elements of a sociological theory of religion, Anchor Books, New York.

Blake, W., 1794, 'The Tyger', in Songs of Experience, publisher unknown, n.p. 
Deist, F., 1984, Nagdissipels: Oor kwelvrae van die geloof, Tafelberg, Kaapstad.

Kaufmann, W., 1956, Existentialism: From Dostoevsky to Sartre, The World Publishing Company, New York.

Lefebvre, H., [1974] 1991, The production of space, Blackwell, Oxford.

Luther, M., 1955-1986, Heidelberg disputation, Luther's work, vol. 31, J. Pelikan \& H.T. Lehmann (eds.), Fortress Press, Philadelphia.

Niemandt, N., 2013, Nuwe leiers vir nuwe werklikhede, Christelike Uitgewersmaatskappy, Vereeniging.

Otto, R., [1917] 1932, Das Heilige. Über das Irrationale in der Idee des Göttlichen und sein Verhältnis zum Rationalen, CH Beck'sche Verlagsbuchhandlung, München.
Sartre, J.-P., 1956, Being and nothingness, Philosophical Library, New York. Sartre, J.-P., 1965, The flies and in camera, Hamish Hamilton, London.

Schleiermacher, F., [1899] 1991, Über die Religion: Reden an die Gebildeten unter ihren Verächtern, 7th edn., Foreword by Rudolf Otto, Vandenhoeck \& Ruprecht, Göttingen.

World Council of Churches, 2012, Together towards Life: Mission and evangelism in changing landscapes: A new WCC affirmation on mission and evangelism, viewed 20 April 2013, from www.oikoumene.org/en/resources/documents/ wcc-commissions/missionandevangelism/together-towards-life-mission-andevangelism-in-changing-landscapes 